NO BILLIONAIRE

LEFT BEHIND 



\section{NO BILLIONAIRE \\ LEFT BEHIND}

Satirical Activism in America

Angelique Haugerud 
Stanford University Press

Stanford, California

(C)2013 by the Board of Trustees of the Leland Stanford Junior University.

All rights reserved.

No part of this book may be reproduced or transmitted in any form or by any means, electronic or mechanical, including photocopying and recording, or in any information storage or retrieval system without the prior written permission of Stanford University Press.

Printed in the United States of America on acid-free, archival-quality paper

Library of Congress Cataloging-in-Publication Data

Haugerud, Angelique - author.

No billionaire left behind : satirical activism in America / Angelique Haugerud.

pages $\mathrm{cm}$

Includes bibliographical references and index.

ISBN 978-0-8047-8152-7 (cloth : alk. paper)--ISBN 978-0-8047-8153-4 (pbk. : alk. paper)

1. Billionaires (Organization) 2. Political satire, American--History and criticism.

3. Street theater--Political aspects--United States--History--21st century. 4. Political activists--United States--Case studies. 5. United States--Politics and government-1989--Humor. I. Title.

E902. $\mathrm{H}_{3} 852013$

339.20973--dc23

2012051065

ISBN 978-0-8047-8631-7 (electronic)

Typeset by Bruce Lundquist in 10/14 Minion 